\title{
Gastrointestinal Pain
}

National Cancer Institute

\section{Source}

National Cancer Institute. Gastrointestinal Pain. NCI Thesaurus. Code C78320.

Painful sensation in the gastrointestinal region. 